\title{
A Classic Maya Mystery of a Medicinal Plant and Maya Hieroglyphs
}

\author{
Jonathan Ferrier ${ }^{1, *} \mathbb{0}$, Todd Pesek ${ }^{2}$, Nicholas Zinck ${ }^{3}$, Sharon Curtis ${ }^{3}$, Phillip Wanyerka ${ }^{4}$, \\ Victor Cal ${ }^{5}$, Michael Balick ${ }^{6}$ and John Thor Arnason ${ }^{7, *}$ \\ 1 Department of Biology, Dalhousie University, Halifax, NS, B3H 4R2, Canada and Board of Education, \\ Mississaugas of the Credit First Nation, Hagersville, ON N0A 1H0, Canada \\ 2 Center for Healing Across Cultures, and School of Health Sciences, Cleveland State University, \\ 2121 Euclid Avenue-HS 101, Cleveland, OH 44115, USA; t.pesek@csuohio.edu \\ 3 Department of Chemistry and Biomolecular Sciences, University of Ottawa, Ottawa, ON K1N6N5, Canada; \\ nzinc079@uottawa.ca (N.Z.); sharon.curtis@live.ca (S.C.) \\ 4 Department of Criminology, Anthropology, \& Sociology (CAS) Cleveland State University, \\ 2121 Euclid Avenue RT 932, Cleveland, OH 44115, USA; P.wanyerka@csuohio.edu \\ 5 Belize Indigenous Training Institute, Punta Gorda, Toledo District, Belize; mavikcal@gmail.com \\ 6 The New York Botanical Garden, Institute of Economic Botany, 2900 Southern Blvd, Bronx, NY 10458, USA; \\ mbalick@nybg.org \\ 7 Biology Department, University of Ottawa, 30 Marie Curie PVT, Ottawa, ON K1N 6N5, Canada \\ * Correspondence: jferrier@dal.ca (J.F.); John.Arnason@uOttawa.ca (J.T.A.)
}

Received: 1 February 2020; Accepted: 17 April 2020; Published: 22 April 2020

check for updates

\begin{abstract}
The Maya employed the $\mathrm{k}^{\prime}$ an $\left|\mathrm{K}^{\prime} \mathrm{AN}\right|$ glyph in Late Classic ( 750 CE) hieroglyphs on murals and polychrome pottery as an adjective meaning precious, yellow. On cacao drinking vessels, the k'an glyph was suggested as a descriptor for a flavoring ingredient, allspice, Pimenta dioica (L.) Merr. (Myrtaceae). However, our previous consensus ethnobotanical fieldwork with Q'eqchi' Maya healers of Belize revealed another candidate among antidiabetic plants, Tynanthus guatemalensis Donn. Sm. (Bignoniaceae), which was the healers' top selection for treatment of diabetes and an exceptionally active extract in an antidiabetic assay for inhibition of protein glycation. Traits of T. guatemalensis observed after cross sectioning the liana were: (1) a cross-shaped xylem organization similar to the k'an glyph; (2) an allspice-like aroma; and (3) yellow color. Based on taxonomy and ethnobotany, confirmation of the allspice-like aromatic compound eugenol, and antidiabetic activity, we determined the plant described by the $\mathrm{k}^{\prime}$ an glyph to be T. guatemalensis (chib'ayal in $\mathrm{Q}^{\prime}$ eqchi'), not $P$. dioica (allspice). In contemporary $Q^{\prime}$ eqchi' tradition, the section of the chib'ayal vine with its cross is associated with the eighth day of their Tzolk'in calendar, which is called the "nawal" (energy) of "q'anil" (ripe, full yellow). This day is represented with a different glyph from the k'an glyph, but notably has a cross representing the four cardinal points. The identification of a potent medicinal plant used in the late classic as well as contemporary times may suggest the long-term preservation of traditional medicinal knowledge in Maya culture for pharmacologically significant plants.
\end{abstract}

Keywords: Maya k'an glyph; Tynanthus guatemalensis eugenol; antidiabetic activity

\section{Introduction}

In the Yukatekan languages, the hieroglyph listed as T281 in the Thompson (1962) catalog [1] (Figure 1) reads k'an [K'AN], meaning "yellow, ripe, or precious" [2]. As an adjective, k'an can relate to anything that can be described as being yellow or yellowish. The $\mathrm{k}^{\prime}$ an glyph is a common cosmogram used by the Classic Maya to invoke cosmic locations, which often links these spiritual locations to precious sacrificial offerings like ripe maize or precious jewels [3]. (To avoid confusion, it is important 
to note that the Yukatekan word k'an has a second meaning and glyph. In the Tzolkin calendar, which is still used in indigenous Maya ceremonies today, $\mathrm{k}^{\prime}$ an is the name of the fourth day, but is represented with a different glyph). In 2012, an article was published on the possible use of the k'an glyph as a description of an ancient ethnobotanically used plant [4]. The glyph is found recorded in numerous hieroglyphic contexts including Classic Maya murals, pottery vessels, and sacred vessels used specifically for beverages made with cacao (Theobroma cacao) (Figure 1). The glyph is a symmetric cross with equal arms but there are many variations, including occasional depictions with tapered arms, like a Maltese cross. According to Freidel et al. [5], the k'an cross symbolizes the four cardinal directions, which provide the basic cosmological framework for describing the surface of the world and, by extension, for individual Mayan communities. In addition, the k'an cross symbolizes the pathway of the sun as it moves daily on its journey across the sky from east to west (ibid.). Each of the four cardinal directions has its own special tree, bird, color, and spiritual personages associated with its domain, and rituals associated with those personages (ibid.). Classic Maya oriented the four cardinal directions to the following four color connotations: East was associated with the color red (chak) and was the most important direction since it represented the direction where the sun was born. North was associated with the color white (sak) and represented the direction from which the cooling winds of winter came. West was associated with the color black (ihk') and it represented the dying place of the sun, and finally, South was associated with the color yellow ( $k^{\prime}$ an) and was considered to be the great side of the sun [6].
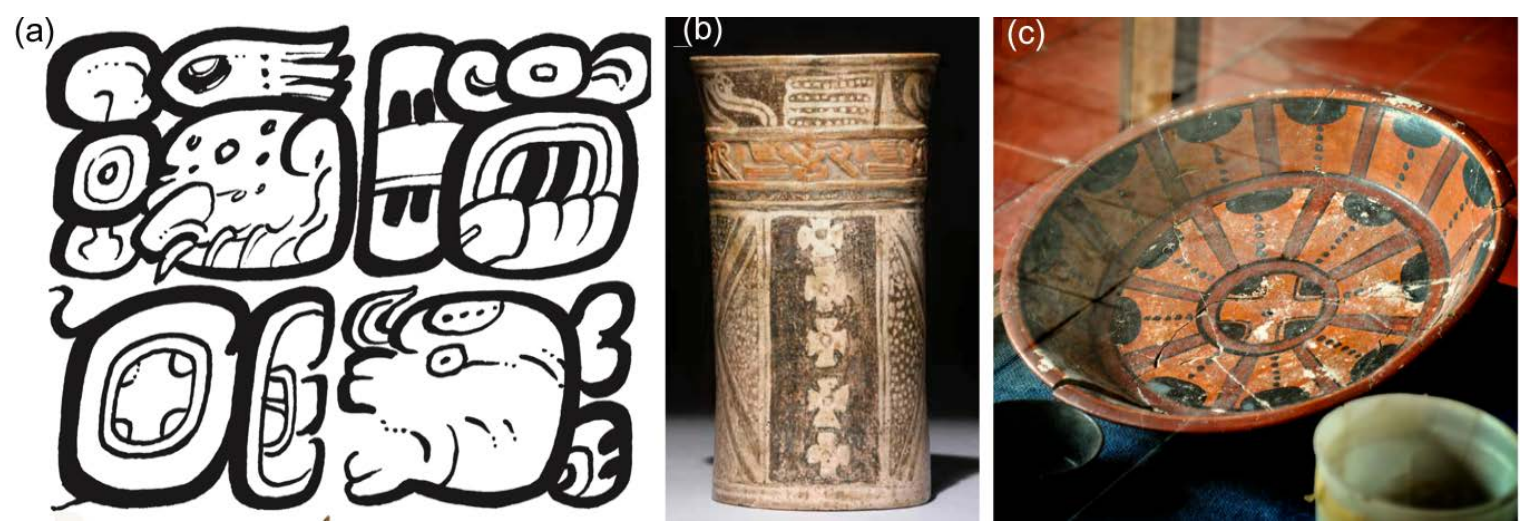

Figure 1. Ways the Maya employ the k'an template with small variations: (a) Drawing of detail of photograph K625 by Justin Kerr (drawing by Marc Zender, used with permission). The whole four-glyph context here reads $y$-uk'ib ta yuta(l) k'an ka(ka)aw or "his drinking vessel for fruity ripe cacao" [1] (Beliaev et al. 2010:260). (b) The k'an cross on Late Classic Maya ceramic cacao vessels (photograph K8804 (C) Justin Kerr, used with permission). (c) The k'an cross in the center of a Late Classic Maya ceramic bowl from Tikal (Photo J. Arnason).

While a variety of trees in the Maya area can be described as "yellow trees" or k'an te or k'an che, [7], we were particularly interested in the use of the glyph on cacao vessels. As reported by Weiss-Krejci [2], k'an serves as an adjective for a specific cacao additive, hitherto read as "yellow, ripe" or "cacao beverage". Working with Maya in Belize, Weiss-Krejci suggested that a plant with the common name "pimiento" was the k'an botanical additive, and identified it as the allspice tree based on its yellowish cross section of the wood with a pattern resembling the k'an cross, yellow bark as well as precious wood, berries which ripen after the harvest, good smell, etc. We hypothesized in the present study that Weiss-Krejci made a logical assumption, but her local informants mistakenly identified the plant described by the glyph as allspice, Pimenta dioica (L.) Merr., a common tree of the family Myrtaceae in the Maya traditional territory and a prominent medicinal plant used widely as an aromatic flavoring agent and tea. 
The objective of this study was to determine which botanical species, based on its anatomical, phytochemical, and medicinal properties was best described by the use of the cross-shaped k'an glyph. This botanical revision led to an important Maya medicinal plant used today, which suggests the continuity of use of some traditional Maya medicines and the reasons for their continued importance.

\section{Materials and Methods}

\subsection{Ethnobotany}

The Q'eqchi' Healers Association comprising five healers and two translators collaborated in the ethnobotanical study. Ethics approvals were issued from University of Ottawa (File H 05-09-07) and the Institutional Review Board of Cleveland State University (File 26228-PES-HS). Ethnobotanical information was collected through a series of open-ended and qualitative ethnographic interviews by Ferrier, Arnason, and Pesek. Participating healers granted prior informed consent and their ethnobotanical knowledge was protected as intellectual property through a research agreement with the University of Ottawa. The use of plants described here is the intellectual property of the Maya healers and should not be used without their permission. Herbarium vouchers and extracts are accessioned at the University of Ottawa, Dalhousie University, the New York Botanical Garden, and the Belize Forestry Office, Belize.

\subsection{Identification of the Eugenol Essential Oil Extraction}

The essential oil from Tynanthus guatemalensis was obtained by solvent extraction of the fresh liana. The liana, $2 \mathrm{~cm}$ in diameter, was cut into $5 \mathrm{~cm}$ long segments and placed in isopropanol. A total of $16 \mathrm{~mL}$ of the solvent was filtered through a $13 \mathrm{~mm}$ nylon $45 \mathrm{~nm}$ syringe filter (Canadian Life Science) to remove particulate matter. The remaining solution was extracted with $4 \mathrm{~mL}$ of hexanes and centrifuged at $1000 \times \mathrm{g}$ for $20 \mathrm{~min}$. The organic phase was collected, washed, and dried over sodium sulphate and concentrated under reduced pressure. The method yielded $0.2 \mathrm{~g}$ of the oil. A total of $200 \mathrm{mg}$ of extracted oil was dissolved in $1 \mathrm{~mL}$ of hexanes for analysis via gas chromatography-mass spectrometry (GC-MS).

\subsection{GC-MS Analysis of Essential Oil Extraction/Fraction}

The GC-MS analysis of the essential oil fraction was carried out on a Hewlett Packard 6890 series GC-MSD with 5913 inert Mass Selective Detector at the John L. Holmes Mass Spectrometry Facility, University of Ottawa. Injector temperature was set to $250^{\circ} \mathrm{C}$ and a $50: 1$ split ratio was employed using helium gas at a rate of $48 \mathrm{~mL} \cdot \mathrm{min}^{-1}$. Separations were performed on a DB-5 column containing $95 \%$ methyl groups, and 5\% phenyl groups (HP 19091A-102, $30 \mathrm{~m} \times 250 \mu \mathrm{m} \times 0.25 \mu \mathrm{m}$ film thickness) at a helium carrier gas pressure of $14.63 \mathrm{psi}$ and a flow rate of $0.9 \mathrm{~mL} \cdot \mathrm{min}^{-1}$. The temperature program was started at $40^{\circ} \mathrm{C}$ and raised to $300{ }^{\circ} \mathrm{C}$ over a $26 \mathrm{~min}$ period at a steady rate of $10^{\circ} \mathrm{C} \cdot \mathrm{min}^{-1}$. The electron impact ionization mass spectra were obtained. Eugenol (cat\# E51791-5G) was obtained from Sigma Aldrich and used as an external standard.

\subsection{Identification of the Essential Oil Component}

Eugenol was identified from the essential oil by matching the mass spectra of the pure compound with the peak eluting at the same retention time under similar chromatographic and spectrometric conditions. Identity was further confirmed by spectral comparison with the Wiley 275 database and the NIST (National Institute of Standards and Technology) Chemistry Web Book entry (http: //webbook.nist.gov/chemistry/). The calculated Kovats Retention Indices were arrived at using the linear retention times of an n-alkane external standard according to the accepted method [8] and compared to the literature values [9]. 


\section{Results}

\subsection{Taxonomic Identification of the K'an Template Based on Wood Anatomy.}

Our ethnobotanical work on antidiabetic plants with Q'eqchi' Maya healers in Belize suggested that a different plant species was the basis of the k'an template, namely a woody liana, Tynanthus guatemalensis Donn. Sm. (chibayal in Q'eqchi') of the family Bignoniaceae.

Common names can cause confusion when the name applies to more than one taxon. In Belize, "pimiento" can allude to both Pimenta dioica (Myrtaceae), which we argue was incorrectly associated with the Maya k'an glyph, and "pimiento bejuco", Tynanthus guatemalensis (Bignoniaceae), an important Q'eqchi' diabetes treatment. The Bignoniaceae family, consisting mostly of tropical trees, shrubs, and lianas, is comprised of approximately 800 species and is not closely related to Myrtaceae. The similar common name arises from the high content of eugenol or its derivatives in both species, lending a distinctive and pleasant allspice-like aroma to both the P. dioica leaf and T. guatemalensis liana. An alternative common name used by the Q'eqchi' healers is chib'ayal.

To solve the mystery of which species was the correct template for the Classic Maya glyph (Figure 1), we worked with Q'eqchi' Maya healers over the course of several years and collected tree and liana stems from the remote and rugged rainforest-covered Maya Mountains as well as from the Q'eqchi' Maya healers' traditional medicinal plant collections at Itzamma (meaning place of Itzamna) Garden, Indian Creek, Belize. Vouchers of P. dioica (OTT 17048) and T. guatemalensis (OTT20003) from Belize were collected and determined by Ferrier, Arnason, and Pesek and compared with a T. guatemalensis type voucher (Smith 1488, NY 328979) and other Central American vouchers of $P$. dioica and T. guatemalensis at the New York Botanical Garden (NY)* (* Information on and photos of $P$. dioica can be found at http://www.tropicos.org/Name/22101787 and for T. guatemalensis at http://www.tropicos.org/Name/3701480). Cross sections of wood for comparison were prepared in the field for both species using a sharp machete. The T. guatemalensis cross section (Figure 2) showed the k'an glyph template clearly, while the $P$. dioica cross section showed concentric growth rings, but no $\mathrm{k}^{\prime}$ an cross. The T. guatemalensis pattern also shows the tapered arms found on some cacao drinking vessels, bowls, and murals [4]. Unusual xylem patterns of various types are common in tropical lianas but rare in trees. In subtropical areas with a distinct dry season, the growth pattern in trees normally shows annual rings similar to temperate trees where growth is interrupted during winter. Although T. guatemalensis is a forest liana and, unlike P. dioica, not easily grown in cultivated sites, the appearance of the $k^{\prime}$ an cross suggests T. guatemalensis was a ritualistic component in Classic Maya art and hieroglyphic texts $[5,6]$.

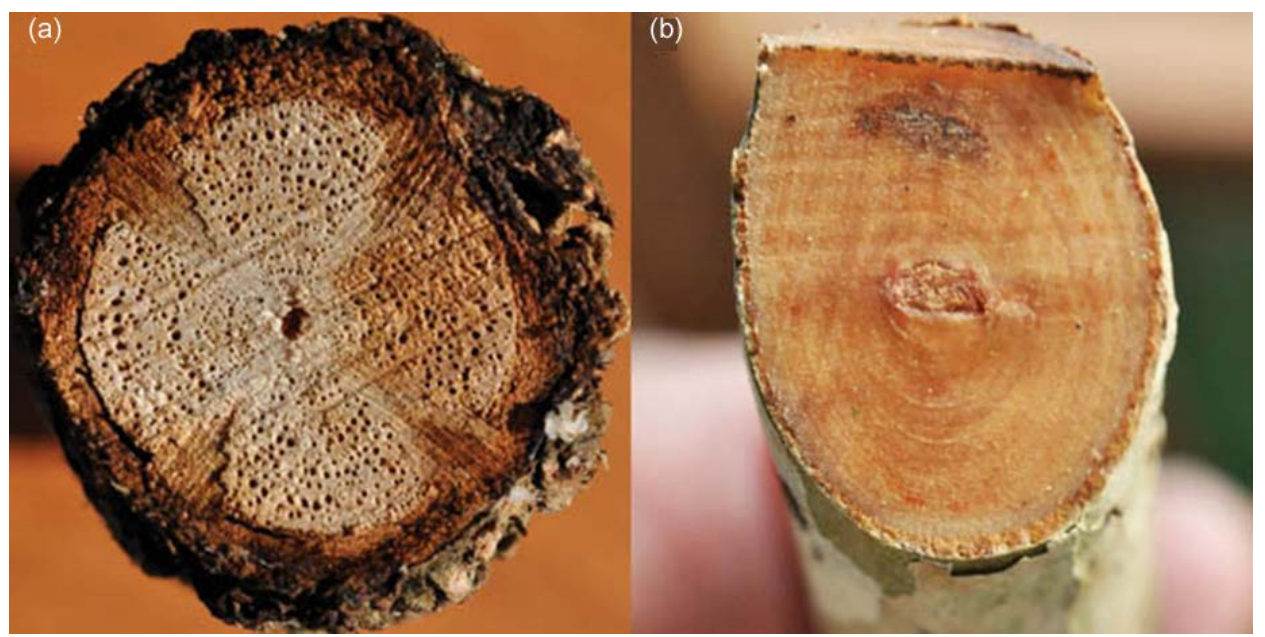

Figure 2. (a) Tynanthus guatemalensis liana cross section showing the k'an sign. (b) Pimineta dioica stem cross section showing concentric growth rings. Stems are approximately $1.5 \mathrm{~cm}$ in diameter. (Photos J. Arnason). 
After cross-sectioning the woody liana, we also observed a pronounced yellow tint in the outer bark and traditional decoction prepared with the stem. P. dioica stems and its traditional decoctions had much less color.

\subsection{Evidence from Flavour and Aroma}

The flavor and aroma of T. guatemalensis is pleasant and strikingly similar to the infusion prepared with $P$. dioica leaves. Since their common names and aroma are similar, taxonomic confusion is not only possible but predictable. Eugenol is a component of $P$. dioica. Our gas chromatography-mass spectrometry (GC-MS) readings of T. guatemalensis isopropyl liquor (Figure 3) compared to an authentic eugenol standard also confirmed the presence of eugenol in the liquor of this species.

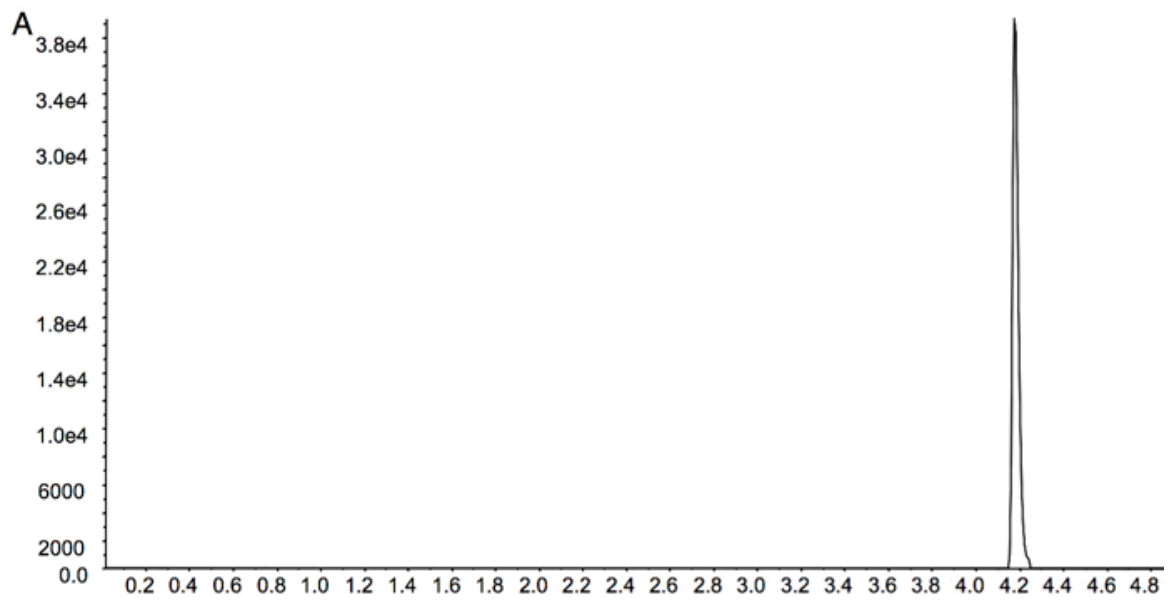

B

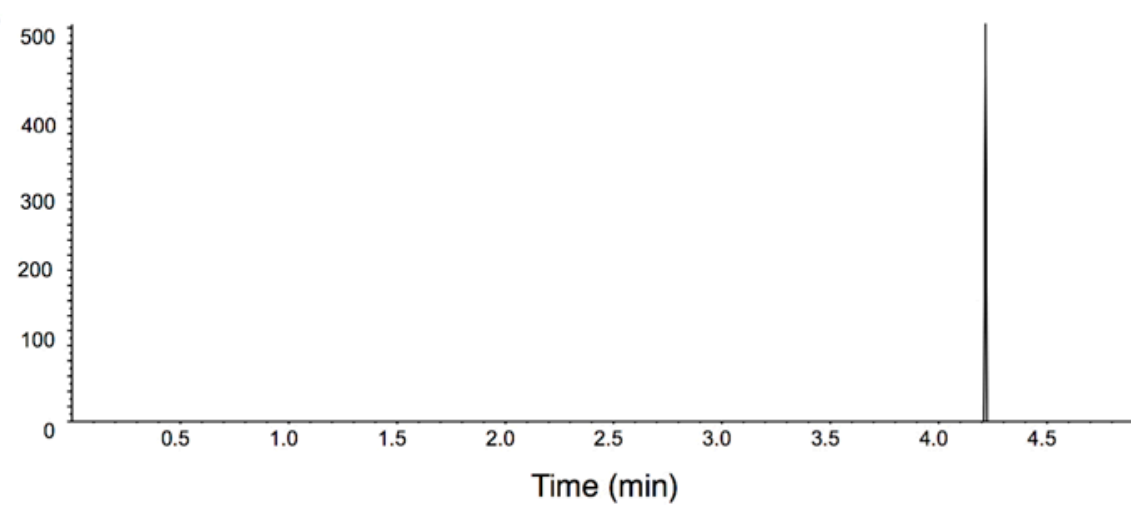

Figure 3. Comparison of retention times (RT) and Kovát's Index (KI) of (A) T. guatemalensis isopropyl liquor $(\mathrm{RT}=14.666 \mathrm{~min} ; \mathrm{KI}=1338)$ and $(\mathrm{B})$ eugenol standard $(\mathrm{Rt}=14.781, \mathrm{KI}=1346)$.

\subsection{Traditional Knowledge}

Although not uncommon, T. guatemalensis is found in primary and secondary semi-evergreen forests, often far away from villages, and effort is required to find and collect the liana. For this reason, Maya medicinal plant specialists (traditional healers), who can identify hundreds of medicinal species $[10,11]$ are aware of the anatomical differences in these two species and rarely confuse them. However, non-specialists among the Maya are often unaware of the difference. We have previously shown that lack of botanical expertise has led to errors in interpretation of ancient Maya botanical use of the ramon tree [12].

\subsection{Ethnobotanical and Ethnopharmacological Studies}

In our research with $Q^{\prime}$ eqchi' Maya healers, T. guatemalensis was recorded as a treatment for diabetes, heart and chest pain, increased thirst, and increased urination. The treatment was prepared 
by crushing $128-\mathrm{cm}$ sections of the liana, plus the root for diabetes, or heart and chest pain, and boiling in $4 \mathrm{~L}$ of water for $30 \mathrm{~min}$. Healers administered the preparation as an infusion to be consumed or applied topically three to four times daily. In the field, the liana was used as a coffee substitute (tea) and the triangular sections outside the xylem were used as cord for fastening tree poles for forest shelters.

The term k'an as used in the archeological context for "precious, yellow" is perhaps best translated in the modern Q'eqchi' language as "q'anil" (yellow, ripe, seed or ready to multiply; for example, the corn of the earth). In contemporary $Q^{\prime}$ eqchi' tradition, the section of the chib'ayal vine with its cross is associated with the eighth day of their Tzolk'in Maya calendar, which is called the "nawal" (energy) of " $q$ 'anil" (ripe, full yellow). This day is represented with a different glyph from the k'an glyph but notably has a cross, which is interpreted as representing the four cardinal points. The Q'eqchi' community and especially traditional healers conduct the Tzolk'in calendar ceremony on a regular basis.

In our previously reported studies [13] on antidiabetic plants from southern Belize with Maya healers, quantitative ethnobotany using the syndromic importance value (SIV) [14] was used to rank the importance of traditional medicines based on treatments for 15 diabetic symptoms including many symptoms, such as poorly healing leg sores, neuropathy, cataracts, and kidney decline which are associated with elevated haemoglobin A1C, a marker for diabetic protein glycation caused by elevated blood glucose. The SIV value for plants developed from healer knowledge was able to predict antidiabetic activity measured in a diabetic anti glycation assay $\left(r^{2}=0.70, p=0.014\right)$. Remarkably, T. guatemalensis had the fourth highest SIV value of 70 plants collected with the traditional healers. For treating diagnosed diabetics (rather than specific symptoms), the healers preferred T. guatemalensis over all other species. Pharmacological studies also showed that T. guatemalensis had the highest antiglycation activity of all plants tested. This activity was associated with the occurrence of the active principle verbascoside, a phenolic compound with potent antioxidant properties [15]. Verbasocside was as active as the positive control, quercetin, in the antiglycation assay. Verbascoside is not known to occur in P. dioica and eugenol was not identified as a potent active principle. Although our results focused on diabetes, the antioxidant effects of phenolics like verbascoside have health benefits in wide areas of application to many degenerative conditions. These data all support the observation that T. guatemalensis is a far more active medicinal species than P. dioica. While more research is needed, our results suggest that $T$. guatemalensis is potentially a superfood similar to blueberry or açai promoting good health. The ancient description of T. guatemalensis by the glyph for "precious yellow" can now be understood in its translation to a modern pharmacological context.

\section{Conclusions}

While many cultivated food plants from Mesoamerica can be traced in the archeological record back to periods as early as 7000 years before present (for example maize), the history and archeological record of medicinal plants, especially from the semi-evergreen tropical forests of the classic Maya heartland in the Peten and Belize are poorly documented, despite evidence of contemporary Maya use of hundreds of species [16-19]. This is perhaps because medicinal plants are mainly herbs that are poorly preserved at archeological sites and are difficult to identify from glyphic texts. Although we cannot be certain, it appears that preservation of aspects of medicinal knowledge over long periods of time may have occurred. If so, it may depend on the enduring medicinal value of the plant as well as the continuing needs of the Maya population over the centuries. The present study shows use in both classic and modern periods for T. guatemalensis, which we showed has remarkable pharmacological activity. Another example is copal incense, obtained by burning the triterpenoid rich resin of Protium copal (Burseraceae), used both in classic and modern Maya spiritual ceremonies. Our pharmacological studies [20] showed that the incense also has remarkable activity as a potent anxiolytic activity, which may explain its long historical use.

Much has been written about Classic Maya civilization and the splendors of their language, astronomy, calendar, architecture, politics, economics, diet, and medicine. Despite conquest, genocide, 
and forest destruction, the endurance of the Maya civilization is evident in contemporary cultural celebrations at Classic Maya city centers. As we have demonstrated, Classic Maya medical heritage recorded on ancient ceremonial vessels (including ceremonial cacao vessels) appears to survive today in the living oral history and medicinal library of living traditional healers. Like Ayurvedic medicine, traditional Chinese Medicine, and Persian traditional medicine, we should accord Maya medicine respect as one of the great medical traditions of the world.

Author Contributions: Conceptualization J.F., J.T.A., T.P., M.B.; Maya epigraphy, P.W.; methodology, field ethnobotany J.F., V.C., J.T.A., T.P.; G.C. analysis, N.Z.; S.C. taxonomy, M.B., J.F.; writing-original draft preparation J.F., J.T.A.; writing - review and editing T.P., P.W., V.C., M.B., S.C. All authors have read and agreed to the published version of the manuscript.

Funding: The project was made possible by funding from: The International Development Research Centre (IDRC-CRDI) of Canada (File \# 105091) and the Aboriginal Health Research Network Secretariat (NEAHR-CIET) of Canada to JA and TP; Discovery Grant from the Natural Sciences and Engineering Council (NSERC- CRSNG) of Canada to JA; and Alexander Graham Bell Ph.D. scholarship to JF. Special project funding came from Naturaleza Foundation and Indigenous Peoples Fund of the World Bank.

Acknowledgments: We thank all members of the Q'eqchi' Healers Association, especially Don Lorenzo Choc (deceased) for sharing their knowledge. We would like to thank Jacqueline Skiffington for her laboratory assistance and artists for sharing figures. We acknowledge editorial services by Sonja Campbell.

Conflicts of Interest: The authors declare no conflict of interest.

\section{References}

1. Thomson, J. A Catalog of Maya Hieroglyphs; University of Oklahoma Press: Norman, OK, USA, 1962.

2. Beliaev, D.; Davletshin, A.; Tokovinine, A. Sweet Cacao and Sour Atole: Mixed Drinks on Classic Maya Ceramic Vases. In Pre-Columbian Foodways: Interdisciplinary Approaches to Food, Culture, and Markets in Ancient Mesoamerica; Staller, J.E., Carrasco, M., Eds.; Springer Science + Business Media: New York, NY, USA, 2010.

3. Stone, A.; Zender, M. Reading Maya Art: A Hieroglyphic Guide to Ancient Maya Painting and Sculpture; Thames and Hudson: London, UK, 2011.

4. Weiss-Krejci, E. Allspice as Template for the Classic Maya K'an Sign. Pari J. 2012, 4, 1-6.

5. Freidel, D.; Schele, L.; Parker, L.J. Maya Cosmos: Three Thousand Years on the Shaman's Path; Harper: New York, NY, USA, 1993; p. 94.

6. Schele, L.; Freidel, D. A Forest of Kings: The Untold Story of the Ancient Maya; William Morrow and Company, Inc.: New York, NY, USA, 1990.

7. Carter, N.; Santini, L. The Lordof Yellow Tree: A New ReferenceTo a Minor Polityon Sacul Stela 9. Pari J. 2019, 4, 1-9.

8. Kováts, E. Gas-chromatographische Charakterisierung organischer Verbindungen. Teil 1: Retentionsindices aliphatischer Halogenide, Alkohole, Aldehyde und Ketone. Helv. Chim. Acta 1958, 41, 1915-1932. [CrossRef]

9. Choi, H.S. Character impact odorants of Citrus Hallabong [(C. unshiu Marcov x C. sinensis Osbeck) x C. reticulata Blanco] cold-pressed peel oil. J. Agri. Food Chem. 2003, 51, 2687-2692. [CrossRef] [PubMed]

10. Balick, M.J.; Arvigo, R. Messages from the Gods; Oxford University Press: New York, NY, USA, 2015.

11. Amiguet, V.T.; Arnason, J.T.; Maquin, P.; Cal, V. A Consensus Ethnobotany of the Q'eqchi' Maya of Southern Belize. Econ. Bot. 2005, 59, 29-42. [CrossRef]

12. Lambert, J.D.; Arnason, J.T. Ramon and Maya ruins: An ecological, not an economic, relation. Science 1982, 216, 298-299. [CrossRef]

13. Ferrier, J.; Saleem, A.; Ramirez, A.C.; Liu, R.; Chen, E.; Pesek, T.; Cal, V.; Balick, M.J.; Arnason, J.T. Traditional medicines used by $\mathrm{Q}^{\prime}$ eqchi' Maya to treat diabetic symptoms and their antiglycation potential. J. Ethnopharmacol. 2018, 224, 504-511. [CrossRef]

14. Leduc, C.; Coonishish, J.; Haddad, P.; Cuerrier, A. Plants used by the Cree Nation of Eeyou Istchee (Quebec, Canada) for the treatment of diabetes: A novel approach in quantitative ethnobotany. J. Ethnopharmacol. 2006, 105, 55-63. [CrossRef] [PubMed]

15. Plaza, P.; Montoro, A.; Benavides, C.; Pizza, C.; Piacente, S. Phenylpropanoid glycosides from Tynanthus panurensis: Characterization and LC-MS quantitative analysis. J. Agri. Food Chem. 2005, 53, 2853-2858. [CrossRef] [PubMed] 
16. Arvigo, R.; Balick, M. Rainforest Remedies: One Hundred Healing Herbs of Belize, 2nd ed.; Lotus Press: Twin Lakes, WI, USA, 1998.

17. Heinrich, M. Ethnobotany and its role in drug development. Phytother. Res. 2000, 14, 479-488. [CrossRef]

18. Meckes, M.; Villarreal MLTortoriello, J.; Berlin BBerlin, E.A. A microbiological evaluation of medicinal plants used by the Maya people of Southern Mexico. Phytother. Res. 1995, 9, 244-250. [CrossRef]

19. Arnason, T.; Uck, F.; Lambert, J.D.H.; Hebda, R. Maya medicinal plants of San Jose Succotz, Belize. J. Ethnopharmacol. 1980, 2, 345-364. [CrossRef]

20. Merali, Z.; Cayer, C.; Kent, P.; Liu, R.; Cal, V.; Harris, C.S.; Arnason, J.T. Sacred Maya incense, copal (Protium copal-Burseraceae), has antianxiety effects in animal models. J. Ethnopharmacol. 2018, 216, 63-70. [CrossRef] [PubMed]

(C) 2020 by the authors. Licensee MDPI, Basel, Switzerland. This article is an open access article distributed under the terms and conditions of the Creative Commons Attribution (CC BY) license (http://creativecommons.org/licenses/by/4.0/). 